\title{
Effects of Seismic Data Acquisition on the Environment - RomSeis Project
}

\author{
Dorina Alina Dragut, Gehrig Schultz, Victor Mocanu \\ Faculty of Geology and Geophysics, University of Bucharest, Bucharest, Romania
}

Email address:

alina_dragut_28@yahoo.com (D. A. Dragut),gehrig.schultz@gmail.com (G. Schultz), victor.mocanu@gg.unibuc.ro (V. Mocanu)

\section{To cite this article:}

Dorina Alina Dragut, Gehrig Schultz, Victor Mocanu. Effects of Seismic Data Acquisition on the Environment - RomSeis Project. International Journal of Environmental Protection and Policy. Vol. 4, No. 3, 2016, pp. 44-48. doi: 10.11648/j.ijepp.20160403.11

Received: March 15, 2016; Accepted: March 24, 2016; Published: April 1, 2016

\begin{abstract}
Complex structures like the Carpathian Orogen and its neighbouring platforms and related inter-orogenic basin system can be understood only by complex integration of complementary investigative tools. A large wide angle refraction and reflection (WARR) survey was carried out in 2014 by a large international partnership in order to study the transition from the East European Platform to the northern part of the Romanian Eastern Carpathians, Transylvanian Basin and the Apuseni Mountains. The main scientific objectives of the WARR project relate to three main investigation domains: crustal architecture; affinity of crystalline basement and sedimentary basins architecture. The profile is about $700 \mathrm{~km}$ in total, in Ukraine and Romania. Recorders used were DSS Cubes and placed at $2.0 \mathrm{~km}$ intervals along an alignment forming the Romanian segment and the seismic sources were explosives, with shotpoints spaced at 20-65 km with a total of 800-1200 kg explosives/site in clusters of drill-holes loaded with $50 \mathrm{~kg}$ explosive/hole, average depth of $25 \mathrm{~m}$. The main conclusions drawn from deep seismic data acquisition technology used is a clean technology, transient, short-lived and do not affect population health, the environmental factors flora and fauna.
\end{abstract}

Keywords: Effects, Deep Data Acquisition, Environment

\section{Introduction}

The Carpathian Orogen is a complex structure and its relationships with the neighboring platforms and related inter-orogenic basin system can be understood only by complex integration of complementary geoscientific investigative tools. In the last decades, the regional geophysical investigations in Romania mainly targeted the Southeast Carpathian Bending Zone, an area named Vrancea [1], [2], [3]. It represents a very peculiar seismogenic zone with a very active intermediate and crustal seismicity characterized by persistency (average of three strong events per century), focal concentration in a limited volume, unique in Europe and one of the three areas like this in the world. This is why areas outside Vrancea remained somehow understudied.

In the summer of 2014, a $700 \mathrm{~km}$ (in Ukraine and Romania) long wide angle refraction and reflection (WARR) survey was carried out by an international consortium in order to study the transition from the East
European Platform to the northern part of the Romanian Eastern Carpathians, Transylvanian Basin and the Apuseni Mountains (Mures river corridor).

The main scientific objectives targeted by WARR in RomSeis 2014 can be allocated to three main investigation domains: crustal architecture (tectonic settings and thermal structure and its control on crustal seismicity); affinity of crystalline basement (identification of autochthonous units and accreted basement units; location and structure of the margin of the East European craton; involvement in basin formation, including structural control and reactivations); sedimentary basins architecture (differentiation between crystalline basement and overlying sedimentary layers; differentiation among sedimentary basins of different tectonic affinity and age; mechanisms of basin formation).

Environmental impact of seismic data acquisition was minimal, for a short time period and had a direct character. Superficial alteration of the natural components was produced and it has a certain reversible character. The rebound of the initial, natural equilibrium had been completed on a short period and did not require external actions. 


\section{Experimental}

RomSeis 2014 WARR had been carried out by a consortium including the University of Bucharest and Prospectiuni S. A. in Romania, University of Aberdeen in the UK, Institute of Geophysics of the Academy of Sciences of Ukraine and the Institute of Geophysics of the Polish
Academy, with important support of GFZ Potsdam in Germany. The deep seismic line connected South Kiev in Ukraine, over the East European Platform, crossed the Eastern Carpathian tectonic units near the RomanianUkrainian border, cut the Transylvanian Depression and crossed the southeastern part of the Apuseni Mts. ending in the Mures corridor (figure 1).

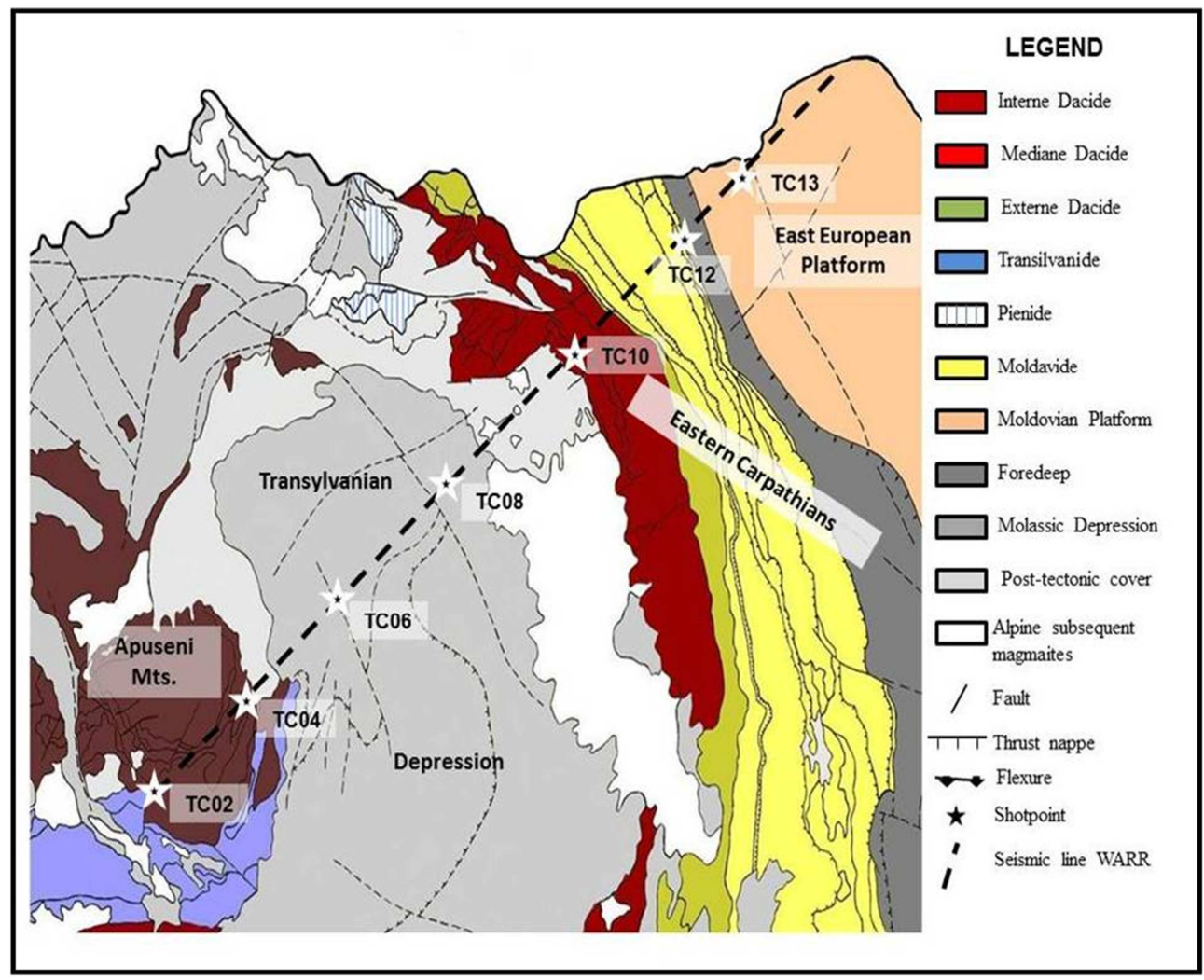

Figure 1. Location of WARR in Romania (modified after map tectono-structural of Romania by Săndulescu, 1984).

The main phases of the acquisition were as following:

- surveying the targeted area in order to decide the location of all sites used for generation and recording the seismic waves;

- getting all working conditions imposed by the decision permitting authorities regarding the drilling, generation and recording of seismic waves;

- information of all authorities and identification of land owners where access permission was required;

- seismic data acquisition.

The criteria for positioning the generation sites were carefully analyzed in order to minimize the potential negative effects on environment, strictly restricted to the access and drilling, as following:

- physical state of the access roads and their use;

- maintaining the safety distances from settlements and any other built up areas with industrial, infrastructure, civilian or military purpose (e.g. wells, oil and gas pipe lines and storage tanks, roads, railways, power lines and other communication structures, water reservoirs, dams, mining operations etc.), objectives of interest at local, regional and national level (springs, water wells, fishing farms, cattle farms, protected flora and fauna) in order to avoid any potential damage;

- topography, cover vegetation, position with respect to neighboring agricultural areas and urban zones;

- avoiding the archaeological sites and historic monuments;

- avoiding protected areas like the ones included in Natura 2000, RO SPA and RO SCII databases;

- lithology, as much as possible to be observed in outcrops and known from references;

- easy logistics (parking of motor vehicles, sitting the drilling rigs and their annexes, temporary storage of lubricants, fuel, anti-pollutant materials, batteries etc.) in such a way that negative impact on the environment and landscape were minimal and on very short term (a few days);

- a special attention was paid to the protection of hydrostatic level in such a way that no interferences with underground waters were noted. The generation sites were selected so that the bottom of all detonation holes were above the hydrostatic level and, if possible, within impermeable formations, not connected to the aquifers placed above them.

The shotpoints were spaced at 20 and $65 \mathrm{~km}$ (figure 1), 
depending on many factors already mentioned and, especially, the access permission for these works.

In Romania, the seismic signal had been recorded by 180 stand-alone geophones spaced every $2 \mathrm{~km}$ along the line and buried at about $30 \mathrm{~cm}$ under the ground, together with the DSS CUBE recorder [4]. They have been protected against humidity using high quality plastic bags and have been fully recovered during the pull-out (figure 2).

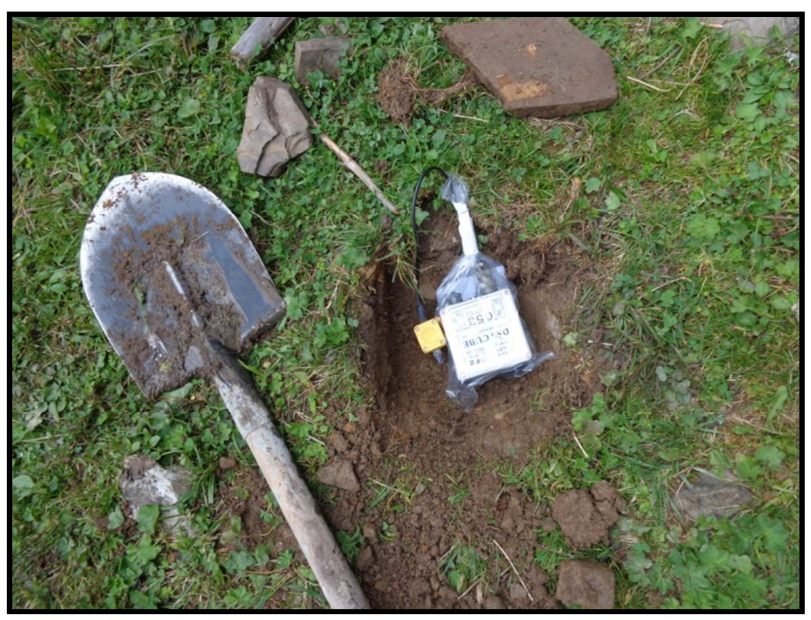

Figure 2. The location in the field of a stand-alone recording system.

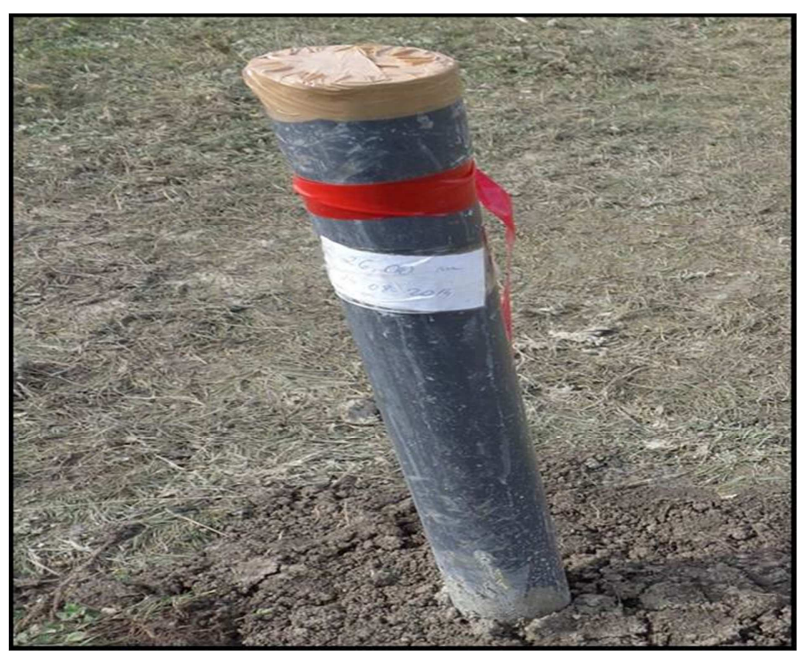

Figure 3. Generation hole and its signaling.

\subsection{Drilling of Generation Holes}

Drilling was carried out on the base of a previously adopted program. For every site, 16 to 24 holes were drilled in a patternnetwork. The individual holes were of $25 \mathrm{~m}$ deep, $12 \mathrm{~cm}$ diameter and spaced at $10 \mathrm{~m}$.

Drilling was performed using a truck mounted hydraulicrotary drilling rig with water circulation for drilling into different types of lithology. Water also had the role of evacuation agent for the cuttings resulted from the drilling operation and was maintained in continuous circulation. As soon as the fluid reaches the surface, it was introduced back into the hole, thus completing a closed circuit. The resulting mud was collected by authorized operators (figure 3) [5].

\subsection{Loading the Shotholes with Civil Explosives}

The generate seismic waves was only done after completion of drilling all holes of the site by authorized, qualified and trained personnel (figure 4) [6]. The quantity of explosive was variable, between 800 and $1200 \mathrm{~kg} /$ site, every generation hole being loaded by $50 \mathrm{~kg}$.

After this stage, the generation hole has been sealed by detritus resulted from drilling or (when detris wasn't available or not enough) clay, with the main target to direct the seismic energy into the depth.

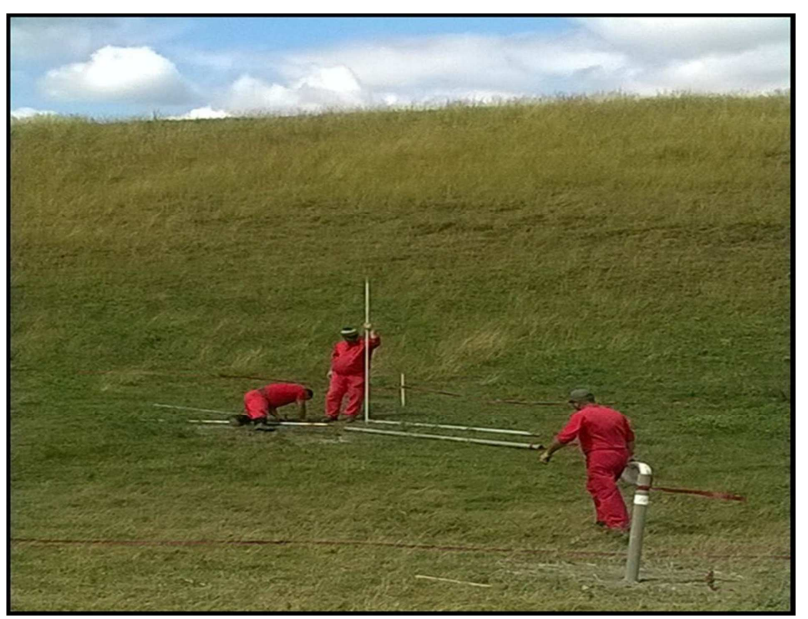

Figure 4. Loading the detonation holes at one of the sites.

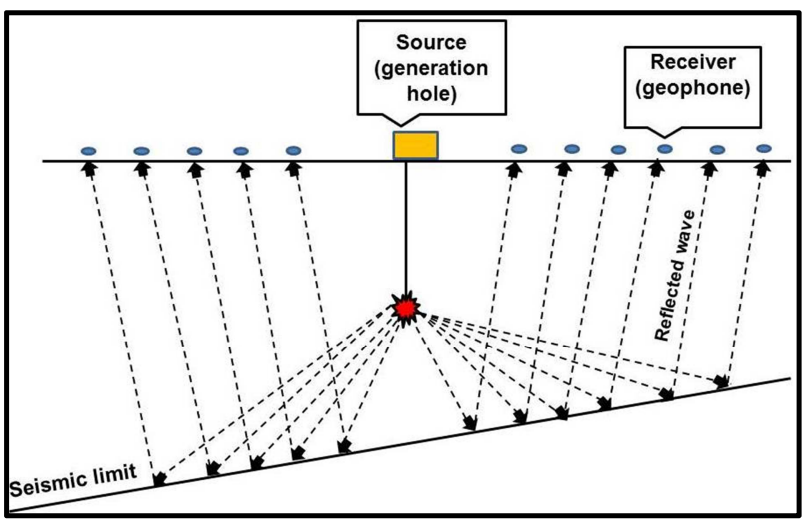

Figure 5. Propagation of elastic waves, simple interaction with the seismic boundary and travel back to the surface where they are recorded by the geophones.

\subsection{Generate Seismic Waves}

The third phase was generating the seismic waves and it was consisting of controlled and simultaneous generation of the explosives in all holes of single sites [7]. This was completed by a very advanced specialized team using a Pelton (back-carried by a team member) [8].

By generating the seismic signal, the resulted waves cross the formations in depth and interact with them in a very complex way (e.g. reflection, refraction etc.) and return to the surface being recorded by the stand alone DSS Cube geophones deployed along the line (figure 5). Various travel times are recorded, depending on many factors but the 
interpreters are mainly interested by the influence of the travelled geological structures which are actually the final target of such a study.

\section{Results and Discussion}

Aquisition of geophysical data was an engineering activity which required deep seismic investigation in order to point out some fundamental aspects of the regional geotectonics as well as potential economically-interesting aspects within the targeted geological formations.

The resulted waste of the drilling and loading operations was immediately collected and transported to the authorized pits [9]. Wastes from the activity of staff (household waste) were carefully and fully collected and handed by authorized service operators in the working area.

Explosive materials used in seismic data acquisition fall into the category "explosives for civil use", very stable in normal conditions of use, storage and handling; moreover, they explosives are not subject to spontaneous combustion.

Following the controlled detonation, the resulting gas compounds generated are carbon monoxide and dioxide ( $\mathrm{CO}$, $\left.\mathrm{CO}_{2}\right)$, nitrogen $\left(\mathrm{N}_{2}, \mathrm{NO}, \mathrm{NO}_{2}\right)$, molecular oxygen $\left(\mathrm{O}_{2}\right)$ and water vapors. This gas compounds are similar to those that are naturally present in the chemical compositions of the atmosphere. Due to the tamping, particle traces or chemical compounds were not detected and on the ground.

No significant impact of the simultaneous generation of elastic waves on the environment was observed (figure 6). Visiting the field area about two months after the acquisition of seismic data, there was no impact of the works on the environment (figures $7 \mathrm{a}$ and $7 \mathrm{~b}$ ) to be observed.

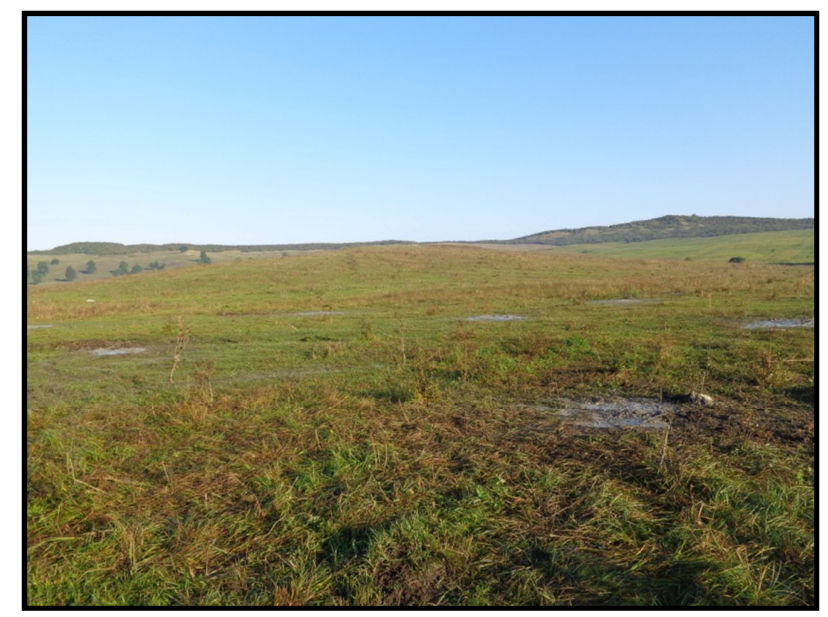

Figure 6. Side effects after simultaneous generation of poorly consolidated land - photo 30 minutes after generation.

\section{Conclusions}

Seismic data acquisition targeted only two aspects, mainly the large scale geotectonic information on Romanian territory and some particular applied aspects in the targeted sedimentary basins. The technology used to record the seismic waves was modern and clean, with minimal environmental impact.

By controlled detonation, settlements and buildings were not affected at all as the generation of seismic waves avoided localities, buildings and constructions of all kind. All land which was used for this project was immediately and completely returned to the initial use by the owners.

No licking of dangerous substances into the surface waters were reported. There was no contamination of any kind, the only class of resulted waste was of household type and they were immediately collected by the contracted, authorized operators.

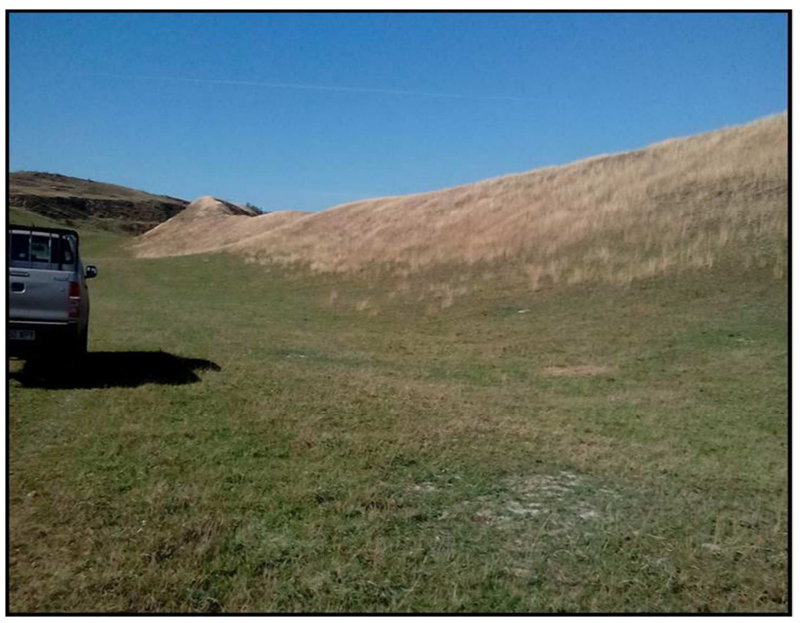

Figure 7a. The side effect after simultaneous generation - photo two months late.

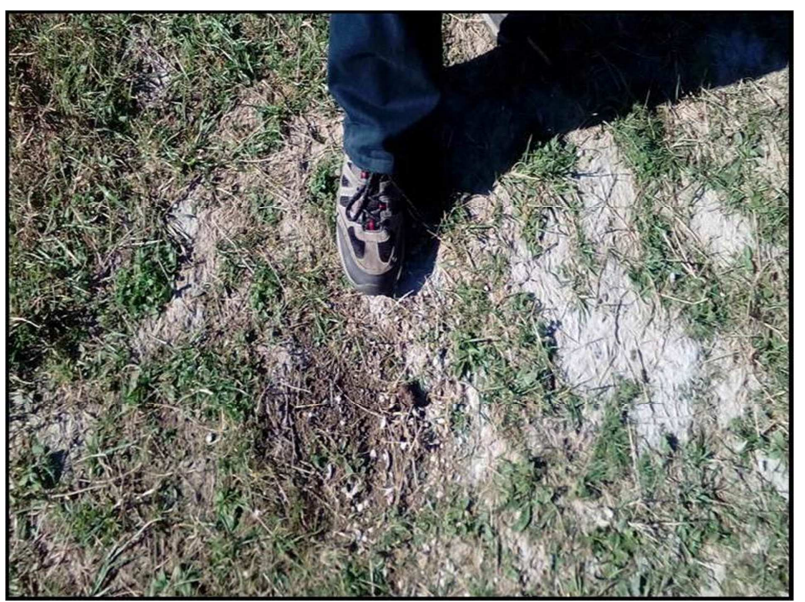

Figure $7 \boldsymbol{b}$. The side effect after simultaneous generation (detail) - photo two months later.

The only real pollution source was represented by the gasses exhausted by the engines used for drilling and related works. Possible pollutants were emissions by fuel burn and the used vehicles and dust resulted on driving on non-paved access roads in areas with no vegetation but this was a normal situation on a daily base for all ordinary activities in the areas. It is widely accepted that the emission of diesel engines have a minimal environmental impact nowadays. A comparison of the air quality, monitored by the environmental authorities in Suceava county for the pre- (July 2014) and post (August 2014) seismic data acquisition proved that the safety actions 
had a prevention character and were very effective, thus the environment was not affected at all [10]. This district was selected as an example as the seismic line crossed several districts.

Table 1. Monthly averages, maximum daily and hourly values for $\mathrm{SO}_{2}$ and $\mathrm{NO}_{2}$ indicators in August 2014 in comparison with July 2014 in Suceava County (according with the Environmental Agency of Suceava County).

\begin{tabular}{|c|c|c|c|c|c|c|c|c|c|c|}
\hline \multirow[t]{2}{*}{ Station } & \multirow[t]{2}{*}{ Polutant } & \multirow{2}{*}{$\begin{array}{l}\text { Data captured } \\
\text { August } 2014 \\
(\%)\end{array}$} & \multicolumn{2}{|c|}{$\begin{array}{l}\text { Maximum of daily } \\
\text { concentration }\left(\mu \mathrm{g} / \mathrm{m}^{3}\right)\end{array}$} & \multirow{2}{*}{$\begin{array}{l}\text { Daily limit } \\
\left(\mu \mathrm{g} / \mathrm{m}^{3}\right)\end{array}$} & \multicolumn{2}{|c|}{$\begin{array}{l}\text { Maximum of average } \\
\text { concentration }\left(\mu \mathrm{g} / \mathrm{m}^{3}\right)\end{array}$} & \multirow{2}{*}{$\begin{array}{l}\text { Hourly } \\
\text { maximum } \\
\text { value }\left(\mu \mathrm{g} / \mathrm{m}^{3}\right)\end{array}$} & \multicolumn{2}{|c|}{$\begin{array}{l}\text { Average monthly value } \\
\left(\mu \mathrm{g} / \mathrm{m}^{3}\right)\end{array}$} \\
\hline & & & July 2014 & August 2014 & & July 2014 & August 2014 & & July 2014 & August 2014 \\
\hline EM3 & $\mathrm{SO}_{2}$ & 0 & 5,97 & - & 125 & 8,62 & - & 350 & 4,95 & - \\
\hline \multirow{2}{*}{ SV1 } & $\mathrm{SO}_{2}$ & 94,2 & 13,17 & 14,67 & 125 & 23,05 & 34,37 & 350 & 6,48 & 9,76 \\
\hline & $\mathrm{NO}_{2}$ & 94,8 & 31,37 & 26,39 & - & 75,38 & 60,91 & 200 & 22,77 & 21,11 \\
\hline SV3 & $\mathrm{NO}_{2}$ & 99,4 & 17,64 & 21,01 & - & 42,17 & 58,16 & 200 & 12,69 & 13,74 \\
\hline
\end{tabular}

The main reason why this was analyzed is that it is just next to the Ukrainian border, so a further comparison with the northern segment of the deep seismic line will be later possible.

In summary, the results of data monitoring of various acidifying pollutants at permanent monitoring stations in Suceavacounty in August 2014 were comparable with the results of the previous month as shown in table 1 .

Noise and vibration noise resulted by generating the seismic signal through detonation of civil explosives, and by autos. The noise had a pulse character of short duration and was within the legal boundaries. There were no complaints of population on discomfort caused by seismic data acquisition in the field.

The underground oil and gas pipelines, communications lines, all types of railways and (high and medium) voltage power lines were strictly avoided. Safety distances to all above were strictly respected, according to the technical aspects of the project and conditions imposed by the central and local authorities as well as the various land owners. The acquisition didn't cause any damage to the surface and underground waters, all sites obeyed the minimal legal distances to the water resources, according to the legislation in place and all safety peculiarities concluded with the authorities.

In conclusion, the environmental impact of acquisition of seismic data by a wide angle refraction and reflection investigation (RomSeis 2014) on environment was on a short time period, and had a direct character. A superficial alteration of the natural components was produced and it has a certain reversible term and did not require external actions.

\section{Acknowledgments}

This project could not be successfully carried out without significant support from our main partner: S. C. Prospectiuni S. A. Romania (Radita Bandrabur and Alexandru Stefan). Other key supporters of this project were from Hunt Oil Romania (Mr. Mark Sturgess and Mr. Mark Wigley), Maxam Romania (Vasile Ionel Catana) and Repsol Spain (George Coman Iusco), Alissa Ionescu - Lukoil Romania; Gheorghe Duțu, Claudia Răileanu and Elena Caramalău of the National
Agency of Mineral Resources of Romania; Laszlo Klarick of the Romanian Senate. I extend my acknowledgments to prof. Randell Stephenson of the University of Aberdeen in the UK for his support before, during and after the acquisition of the seismic data.

Also, I would like to acknowledge the support of POSDRU/159/1.5/S/133391, Project "Doctoral and PostDoctoral programs of excellence for highly qualified human resources training for research in the field of Life sciences, Environment and Earth Science" co-financed by the European Social Fund within the Sectorial Operational Program Human Resources Development 2007 - 2013.

\section{References}

[1] Hauser, F., Raileanu, V., Fielitz, W., Bala, A., Prodehl, C., Polonic, G., Schulze, A., (2001). VRANCEA99-the crustal structure beneath the southeastern Carpathians and Moesian Platform from a seismic refraction profile in Romania. Tectonophysics 340, 233-256.

[2] Hauser, F., Prodehl, C., Landes, M., VRANCEA working group, (2002). Seismic experiments target earthquake-prone region in Romania. EOS Trans. AGU 83, 457-463.

[3] Raileanu, V., Bala, A., Hauser, F., Prodehl, C., Fielitz, W., (2005). Crustal properties from S-wave and gravity data along a seismic refraction profile in Romania. Tectonophysics 410, 251-272.

[4] www.gfz.potsdam.de

[5] Simms, J., Yaramanci, U., (2013). Foreword to the Special Issue on Geotechnical Assessment and Geo-environmental Engineering Geophysics. Journal of Environmental \& Engineering Geophysics, Vol. 18, Issue 4, 199.

[6] www.maxam-corp.co.za/

[7] www.dcenr.gov.ie.

[8] www.iagc.org.

[9] Ianos, I., Peptenatu, D., Zamfir, D., (2009). Respect for environment and sustainable development. Carpathian Journal of Earth and Environmental Sciences, Vol. 4, No. 1, 81-93.

[10] www.anpm.ro. Environmental Status Report in Suceava County month August 2014. 